\title{
MIGRAREA SATULUI ROMÂNESC ÎN EUROPA OCCIDENTALĂ
}

\author{
Ion-Narcis MUNTEANU*
}

\begin{abstract}
Migration of the Roumanian village to Western Europe ${ }^{1}$. The migrant, leaving the Orthodox Romanian traditional village to move to Western Europe, notes that surprisingly the Orthodox Christians were majority in his village, but in the host country are a minority. This is the first reason for him to try to rebuild the universe of his traditional village in Diaspora, which gives him the feeling of safety and stability. The church becomes the "meeting place of the village" that he recreates next to those he called or those he later helped to migrate, relatives and friends, to be "all of them together". Here, the practice of sacred ancestral traditions continues, which helps him to overcome the impact caused by the isolation of the Western individual, unlike the spirit of the community and the hospitality with which he was accustomed. In my work I will highlight the mission of the priest in the Romanian communities of the Orthodox Diaspora of Western Europe for the preservation of the religious and cultural values characteristic of the traditional Romanian village, in contrast with the pressure for renewal and integration in the culture of the host country.
\end{abstract}

Keywords: migrants, diaspora, Romanian village, Christian traditions.

\section{Introducere}

Migranții români stabiliți în Europa Occidentală au încercat și au reuşit să reconstruiască acolo atmosfera din satul românesc tradițional pe care 1-au părăsit, prin păstrarea tradițiilor și a vieții bisericești de acasă.

* Priest, PhD Student, Faculty of Orthodox Theology at University from Craiova, Romania.

${ }^{1}$ Studiu realizat sub îndrumarea Arhid. Conf. Univ. Dr. Gelu Călina, care şi-a dat acordul pentru publicare. 
Scopul acestui articol este să demonstreze că sentimentul de stabilitate este esențial pentru identitatea fiecărui om, iar Biserica noastră și-a adus din plin aportul la asigurarea acestuia în orice context occidental.

Intrarea României în spațiul Uniunii Europene reprezintă nu doar șansa românilor de a-și îmbunătăți nivelul de trai și de a avea acces la cultura și civilizația vest-europeană, ci și ,îmbogăţirea Uniunii Europene cu cultura şi spiritualitatea românească şi, în mod particular, cu valorile ei religioase"2. În acest sens, Prea Fericitul Patriarh Teoctist sublinia: „Reafirmăm cu tărie necesitatea valorilor noastre creştine româneşti tradiţionale, astfel încât să dăm posibilitatea Europei să vadă în noi, românii, pe păstrătorii unui tezaur de spiritualitate, pe care avem datoria să-1 împărtăşim şi altora"3.

Libera circulație a persoanelor, mărfurilor, capitalurilor și cunoștințelor tehnico-ştiinţifice constituie, desigur, avantaje ale procesului de globalizare. Globalizarea reprezintă însă „o gigantică mutație civilizațională care traumatizează societățile, manifestându-se printr-o ruptură tot mai evidentă cu ierarhiile de valori ale culturilor tradiționale"4. Printre efectele sale negative se numără anularea omului ca persoană relațională și promovarea unei culturi a consumului ${ }^{5}$.

Libera circulație, efect al globalizării, are numeroase consecințe și asupra românilor care decid să migreze. Părăsirea mediului inițial, care le asigura stabilitate, încredere, respect, iubire, face ca după migrarea într-o altă țară ei să se simtă tot timpul marginalizați, întâmpinând bariere de ordin etnic, religios, lingvistic, cultural sau relaţional. Efectele negative

2 Nicolae D. Necula, „Cultul divin public ortodox, factor de stabilitate în viaţa credincioşilor", în Adrian GABOR, Radu Petre MUREŞAN (coord.), Biserica Ortodoxă în Uniunea Europeană. Contribuţii necesare la securitatea şi stabilitatea europeană, Bucureşti, Edit. Universităţii din Bucureşti, 2006, p. 21.

3 „Mesajul Prea Fericitului Părinte Patriarh Teoctist la Forumul Naţional U. E. 2007”, 14 februarie 2003, în VestitorulOrtodoxiei, nr. 308-309/2003, p. 5.

${ }^{4}$ Ioan ICĂ Jr., „Globalizarea - mutații și provocări”, în Gândirea socială a Bisericii. Fundamente - documente - analize - perspective, volum realizat şi prezentat de Ioan Ică Jr. şi Germano Marani, Sibiu, Edit. Deisis, 2002, p. 481.

5 Radu Petre Mureşan, ,Provocări și perspective ale Bisericii Ortodoxe în Uniunea Europeană”, în Adrian GABOR, Radu Petre MuREșAN (coord.), Biserica Ortodoxă în Uniunea Europeană. Contribuţii necesare la securitatea şi stabilitatea europeană, p. 165. 
ale migrației sunt resimțite mai puternic de către românii proveniţi din satele tradiționale, dar aceștia sunt cei care reușesc, inclusiv prin păstrarea tradițiilor, să evite consecințele, uneori devastatoare în plan moral, ale dezrădăcinării și ale confruntării cu modernitatea.

În lucrarea sa, Cultură și experiență de migrație în satele României, profesorul Dumitru Sandu face o împărțire a satelor din România. El identifică șase tipuri. Unul dintre aceste tipuri de sate este cel tradițional ${ }^{6}$. Studiul relevă faptul că doar un procent de $14 \%$ din populația rurală a țării locuiește în sate de tip tradițional ${ }^{7}$, care sunt caracterizate printr-o lipsă a experienței legate de migrație, precum și printr-un așa-numit tradiționalism religios și o încredere mare în Biserică ${ }^{8}$. Membrii satului tradiţional sunt mai puțin pregătiţi pentru impactul reprezentat de migrație, datorită lipsei unei experiențe a diversității culturale și a alterității ${ }^{9}$. Studiul relevă faptul că locuitorii satului tradițional românesc manifestă o reticență sporită față de migrația într-o altă țară, datorită în special înrădăcinării mai puternice în spațiul comunitar al satului tradiţional, locul în care au tot ceea ce le oferă siguranță: pământul, casa, familia, prietenii.

Este motivul principal care îi determină pe români să încerce să reconstruiască în diaspora universul satului lor tradiţional ce le conferă sentimentul de siguranță și stabilitate. Ei doresc „,să se mute cu tot satul în străinătate", iar pentru aceasta reconstruiesc în Europa Occidentală mediul familial al satului tradiţional.

Ajuns în străinătate, săteanul își găsește locuință, loc de muncă, începe să câștige bani, dar se simte singur și neîmplinit. Ține legătura cu cei de acasă mai ales telefonic și încearcă să îi aducă pe câți mai mulți dintre aceștia la el, rude sau prieteni. Unora le găsește locuri de muncă, părinților le propune să aibă grijă de nepoți. Găsește un motiv pentru a-i atrage pe fiecare dintre aceștia, scoțând în evidență mai ales posibilitatea de a câștiga mai mult și de a trăi mai bine. Dorește să refacă comunitatea din satul său tradițional și face multe eforturi în acest sens.

\footnotetext{
${ }^{6}$ Dumitru SANDU, ,, Cultură și experiență de migrație în satele României”, în Sociologie Românească, Nr. 3/2004, p. 180.

${ }^{7}$ Ibidem, p. 187.

${ }^{8}$ Ibidem, p. 191.

${ }^{9}$ Ibidem, p. 194.
} 
Dacă în țară a fost doar un credincios nepracticant, aici el devine practicant și Îl caută cu înfrigurare pe Dumnezeu. Merge mai întâi în locaşurile de cult ale fraților ortodocși greci sau ruși, dacă există în localitate, dar își dorește o biserică în care să se slujească românește. Un preot va fi trimis aici de către structurile din diaspora ale BOR numai dacă există o comunitate suficient de mare pentru a justifica necesitatea înființării în acel loc mai întâi a unei misiuni, apoi a unei filii a altei parohii și abia în cele din urmă a unei parohii de sine stătătoare.

Biserica romano-catolică sau protestantă închiriată, împodobită doar în timpul slujbelor religioase cu icoane ortodoxe, îl face să-și dorească construirea unei biserici tradiţionale, precum cea din satul său, pictată și împodobită cu iconostas de lemn sculptat, cu strane și mobilier bisericesc ce au imprimate motive populare românești. Biserica devine „locul de întâlnire al satului” pe care îl recreează alături de cei pe care ia chemat sau de cei pe care i-a ajutat ulterior să migreze, rude și prieteni, pentru a fi ,ai lor, toți laolaltă”. Fără Biserică, și-ar pierde în scurt timp identitatea, membrii ei fiind ușor asimilați de către băștinași și de cultura acestora, inclusiv prin formarea unor familii mixte.

\section{Cultul divin public și sentimentul de stabilitate}

Un element esenţial în crearea sentimentului de stabilitate a vieții credincioșilor din străinătate îl reprezintă cultul divin public, care sintetizează învăţătura de credinţă sub forma rugăciunii şi a cântărilor religioase. Cultul ortodox poartă pecetea Bisericii Ortodoxe Române ${ }^{10}$, fiind „un tezaur de învăţătură şi de spiritualitate"11.

În decursul istoriei, cultul divin public, în afară de rolul său esențial de satisfacere a nevoilor sufletești ale enoriașilor, a îndeplinit și rolul de menținere a unităţii românilor din diferitele regiuni istorice românești, precum și a credinței și tradiţiilor strămoșești ale acestora. $\mathrm{Cu}$ atât mai mult, pentru comunitățile de români din diaspora care au migrat din sate tradiţionale românești și care doresc să reconstituie acolo atmosfera satului tradițional, cultul public are un rol esențial.

${ }^{10}$ Ene BRANIŞTE, „Cultul ortodox ca mijloc de propovăduire a dreptei credinţe, a dragostei, a păcii şi a bunei înţelegeri între oameni”, în Studii Teologice, 9-10/1953, p. 626-642.

${ }^{11}$ Idem, Liturgica generală, vol. I, Galaţi, Edit. Episcopiei Dunării de Jos, 2002, p. 68. 
Pentru practicarea sa este însă nevoie de existența unor locaşuri de cult în care creștinii să găsească ,adăpost şi mângâiere, stabilitate şi siguranţă"12. Locașul de cult îi ajută să își păstreze credința, tradițiile și obiceiurile, dar mai ales unitatea comunității. Simt aici ajutorul lui Dumnezeu, simt că Îl au alături în nevoile și încercările la care sunt supuşi în țara gazdă. Se simt apărați de toate influențele negative care tind să le răstoarne altfel sistemul de valori morale prin acceptarea ca stare de normalitate a unor păcate, cu care nu erau obișnuiţi în satul tradiţional românesc de provenienţă, totul în baza unor așa-numite toleranțe. În biserică, prin cultul divin public, prin cinstirea sfinților, creștinii învață care sunt normele morale și sociale pe care omul trebuie să le îndeplinească pentru a trăi corect în societatea occidentală, dar și pentru a nu își pierde mântuirea. În biserică, prin participarea la cultul public, credincioșii învață despre, ,ideile de dreptate socială, de iubire şi de apreciere a semenului, de întrajutorare şi de respect a fiinţei umane şi a valorilor sociale şi morale de pace, egalitate, fraternitate, smerenie şi răbdare, pe seama cărora se poate construi edificiul încrederii între oameni şi naţiuni, climatul de stabilitate şi securitate"13.

\section{Român creștin ortodox în Europa Occidentală}

Convenția Europeană a aprobat articolul 37 al Constituției Europene, care alături de articolul 10 al Cartei Drepturilor Fundamentale ale Europei reglementează relația dintre Stat și Biserică ${ }^{14}$ din cadrul Uniunii Europene ${ }^{15}$. Acestea stipulează dreptul oricărui cetățean european de a practica propria religie, de a adopta o altă religie sau de a nu practica nici o religie. A fost, de asemenea, prevăzut principiul

12 Nicolae D. NECULA, „Viaţa religioasă în Biserica Ortodoxă Română”, în vol: Biserica în Misiune. Patriarhia Română la ceas aniversar: 120 de ani de autocefalie (18852005), 80 de ani de Patriarhat (1925-2005), Bucureşti, EIBMBOR, 2005, p. 343.

13 Ene BRANIŞTE, „Cultul ortodox ca mijloc de propovăduire a dreptei credinţe, a dragostei, a păcii şi a bunei înţelegeri între oameni”, p. 634.

${ }^{14}$ Relația dintre Stat și Biserică nu trebuie confundată cu relația dintre religie și politică, ci se referă la relația dintre autoritatea civilă și autoritatea religioasă.

${ }^{15}$ Silvio FerRARI, „The Secular and Sacred in Europe's Constitution”, în The Spiritual and Cultural Dimension of Europe, Luxembourg, Office for Official Publications of the European Communities, 2005, p. 21. 
separației dintre Biserică și Stat, evidențiindu-se însă necesitatea unui dialog permanent între Uniunea Europeană și confesiunile religioase de pe teritoriul ei. A fost stipulate și faptul că Uniunea Europeană va permite fiecărui stat membru să aibă un statut propriu al cultelor de pe teritoriul lor în conformitate cu legislația națională. Deși cultele par să se bucure de o anumită autonomie în cadrul Uniunii Europene, aceasta este limitată, deoarece foarte multe dintre dispoziţiile legale impuse de către Uniune în diferite domenii precum dreptul familiei, al muncii, fiscal, al asigurărilor sociale etc. au incidență asupra sa. În pofida numeroaselor solicitări făcute în acest sens, nu a fost însă inclusă în Constituţia Europeană nici o mențiune la originea creștină a Europei. Este urmarea firească a organizării procesului de extindere continuă a Uniunii Europene, care vrea să încurajeze intrarea în această uniune a unor țări musulmane, cel mai important candidat în acest sens fiind Turcia ${ }^{16}$.

În vederea afirmării şi apărării intereselor sale, Biserica Ortodoxă Română a înființat în anul 2000 o reprezentanță a sa pe lângă organismele europene, iar în anul 2006, cu ajutorul statului român, a achiziţionat pentru această reprezentanță a sa un sediu la Bruxelles. BOR depune eforturi constante în sensul prezervării tradiţiilor naţionale şi religioase ale românilor din Europa Occidentală, implicit a celor care sunt legate de viața rurală tradițională. În acest sens se înscrie și înființarea în Europa Occidentală de către BOR a celor două mitropolii: Mitropolia Ortodoxă Română pentru Germania, Europa Centrală și de Nord (anul 1994) şi Mitropolia Ortodoxă Română a Europei Occidentale și Meridionale (anul 1999) $)^{17}$.

Putem afirma că relația dintre Stat și Biserică în România este diferită de cea existentă în alte state ale Uniunii Europene, unul dintre factorii determinanţi fiind procentul foarte mic, de doar $0,2 \%$ din totalul celor 20 milioane de români, reprezentat de cei care s-au declarat fără

16 Viorel BUŢA, „Modernitate şi tradiţie privind aspectele culturale ale extinderii europene", în A. GABOR, R. P. MureşAN (coord.), Biserica Ortodoxă în Uniunea Europeană..., p. 19.

17 Patriciu VlaicU, „Românii din Europa Occidentală și Meridională”, în PS Ciprian CÂmpInEAnu et all (eds.), Autocefalie și comuniune, București, Edit. Basilica a Patriarhiei Române, 2010, p. 573. 
religie sau atei la recensământul populației din anul $2011^{18}$. Relația dintre Stat și Biserică în România este diferită de cea din Franța sau Olanda, care se caracterizează printr-o separație radicală, dar este diferită și de cea din Grecia sau Țările Nordice, unde există biserici de stat. Relația dintre Stat și Biserică în România poate fi asemănată cu cea din Belgia, Cehia, Slovacia sau Austria ${ }^{19}$.

\section{Satul românesc din diaspora și respectarea tradițiilor sale}

Satul tradițional românesc din Europa Occidentală are în centrul său biserica, locașul de cult. Aici părinții merg împreună cu nașii, rudele și prietenii să încreștineze pruncul prin Botez. Aici se cunună tinerii. Aici se săvârșeşte slujba înmormântării, dar și mulțimea rânduielilor legate de pomenirea celor răposați. Aici se mărturisesc și se împărtășesc, aici se roagă împreună prin rugăciunea comună și practicarea cultului divin public. Este locul în care, alături de participarea la cultul divin public, vorbesc românește, împărtășesc noutățile din țară sau din comunitate, se susțin reciproc, se ajută, locul în care tineri și tinere se cunosc și formează noile familii de români.

Un rol esențial îl are însă preotul, care nu trebuie să se ocupe doar de săvârşirea slujbelor religioase, ci trebuie și să vegheze la protejarea vieții comunitare, intervenind în aplanarea conflictelor apărute în viața parohiei. Preotul mobilizează pe enoriași pentru dotarea locaşului de cult cu cele necesare: icoane, cărți și obiecte de cult, veșminte bisericești. El păstrează permanent, prin intermediul protopopiatului, legătura cu eparhia sub a cărui jurisdicție se află și implicit cu Biserica-mamă. El se implică, cu ajutorul enoriaşilor, în ajutorarea noilor veniţi prin găsirea unor locuințe, dar și a unor locuri de muncă stabile, totul din dorința de a menține comunitatea parohială unită. Într-o societate caracterizată prin consumism, prin globalism urban non identitar, omul nevoit să-și

18 Institutul NAȚIONAL de STATISTICĂ: Rezultate definitive ale Recensământului Populaţiei şi al Locuinţelor-2011(caracteristici demografice ale populaţiei), 2011, disponibil la: http://www.recensamantromania.ro/wp-content/uploads/2013/07/ REZULTATE-DEFINITIVE-RPL_2011.pdf, (accesat la: 15. 03. 2019).

19 Adrian LEMENI, ,, Raportul dintre Stat şi Biserică în România în perspective integrării în Uniunea Europeană”, în: A. GABOR, R. P. MuREŞAN (coord.), Biserica Ortodoxă în Uniunea Europeană..., p. 146. 
schimbe frecvent domiciliul, în încercarea permanentă de a găsi un loc de muncă mai bine plătit, simte nevoia de stabilitate, iar această stabilitate o oferă biserica, mai ales prin practicarea cultului divin, având în centru săvârșirea Sfintei Liturghii.

Participarea sătenilor la Sfânta Liturghie are meritul că retrezește în comunitatea rurală transplantată în Occident sentimentele frățești. Aceștia devin conștienți de faptul că bunurile materiale pe care reușesc să le achiziționeze mai ușor muncind în Occident, tehnologia și informația la care au acces, nu reușesc să le ofere fericirea așa cum se așteptau. Înțeleg că omul este o ființă comunitară și că pentru el este foarte importantă atât familia, dar și comunitatea în care trăiește, cu menținerea tuturor tradițiilor și obiceiurilor pe care le cunoștea din satul tradițional pe care 1-a părăsit.

În luna mai a anului 2017, Ministrul pentru Românii de Pretutindeni, Andreea Păstîrnac, afirma faptul că în anul 2016 s-au născut mai mulți copii în străinătate decât în România ${ }^{20}$. Această afirmație ne înfățișează o dată în plus amploarea fenomenului migrației din România în Europa Occidentală, în special a tinerilor care reprezintă categoria de populație aptă de muncă și cu o capacitate sporită de adaptare la noul mediu socio-cultural.

În cadrul comunităților de români ortodocşi din străinătate se păstrează tradițiile satului românesc în special prin respectarea obiceiurilor legate de sărbătorile de Paști și de Crăciun, prin respectarea obiceiurilor legate de momentele nașterii pruncilor și al Botezului acestora, prin respectarea tradițiilor legate de Căsătorie, eveniment care marchează intrarea într-o nouă etapă a vieții persoanei ${ }^{21}$, precum și prin respectarea obiceiurilor și tradițiilor legate de moarte și de împlinirea cultului morților.

Procesul globalizării și al secularizării duce însă la dispariția culturii tradiționale care este privită uneori ca o marfă sau devine simplu spectacol.

20 Andreea PĂSTîRnAC, Interviu, disponibil la: http://www.mprp.gov.ro/web/ministrulpentru-romanii-de-pretutindeni-andreea-pastirnac-ma-uit-la-toti-cei-care-sunt-in-fatanoastra-ca-la-parteneri-dintr-o-perspectiva-care-vreau-sa-ramana-onesta/ (accesat la: 18. 03. 2019).

21 EuracAdemy Association, Rural heritage and collective identity. Building the sustainability of rural comunities, Atena, Prisma, 2009, p. 60. 
Omul nu se poate opune globalizării, dar poate să se păstreze ca persoană apărându-și conștiința, religia sau cultura tradițională de efectele societății de consum care tinde să îl acapareze treptat. Modernitatea face presiuni pentru eliminarea religiei din viața socială, iar „omul uită de valorile spirituale, care îl înalţă spre asemănarea cu Dumnezeu, și se lansează întro cursă frenetică după bunurile materiale ale acestei lumi, care nu vor fi niciodată îndestulătoare pentru setea omului după eternitate"22.

\section{Concluzii}

Satul românesc reconstruit în Europa Occidentală asigură sentimentul de siguranță și stabilitate al membrilor ei. Elementele sale constitutive sunt oamenii, biserica și tradițiile creștine. Preotul joacă un rol foarte important în păstrarea valorilor religioase și culturale caracteristice satului românesc tradițional.

Comunitățile ortodoxe românești pot contribui în mod hotărâtor la crearea și păstrarea unui climat de stabilitate în această parte a Europei prin afirmarea frumuseții valorilor morale tradiționale românești și prin arătarea modului în care românii din Occident pot să trăiască în spiritul acestor valori. Într-o Europă supusă globalizării și secularizării ei vor fi caracterizați prin cuvintele autorului necunoscut al Epistolei către Diognet: „Nu se deosebesc de ceilalţi oameni nici prin pământul pe care trăiesc, nici prin limbă, nici prin îmbrăcăminte...Urmează obiceiurile băştinaşilor şi în îmbrăcăminte şi în hrană şi în celălalt fel de viaţă, dar arată o vieţuire minunată şi recunoscută de toţi ca nemaivăzută"23.

\section{Referinţe bibliografice:}

1. BRANIŞTE, Ene, „Cultul ortodox ca mijloc de propovăduire a dreptei credinţe, a dragostei, a păcii şi a bunei înţelegeri între oameni”, în Studii Teologice, 9-10/1953, p. 626-642;

2. BRANișTe, Ene, Liturgica generală, vol. I, Galaţi, Edit. Episcopiei Dunării de Jos, 2002;

22 Dumitru POPESCU, „Omul fără rădăcini”, în Dumitru POPESCU (ed.), Știință și teologie: preliminarii pentru dialog, București, Edit. XXI: Eonul dogmatic, 2001, p. 291.

${ }^{23}$ Epistola către Diognet, în Scrierile PărinţilorApostolici, traducere în limba română de Dumitru FECIORU, Bucureşti, EIBMBOR, 1995, p. 412. 
3. BuțA, Viorel, „Modernitate şi tradiţie privind aspectele culturale ale extinderii europene", în Adrian GABOR, Radu Petre MUREŞAN (coord.), Biserica Ortodoxă în Uniunea Europeană. Contribuţii necesare la securitatea şi stabilitatea europeană, Bucureşti, Edit. Universităţii din Bucureşti, 2006, p. 14-20;

4. Epistola către Diognet, în Scrierile Părinţilor Apostolici, traducere în limba română de Dumitru FECIORU, Bucureşti, EIBMBOR, 1995;

5. EURACADEMY ASSOCIATION, Rural heritage and collective identity. Building the sustainability of rural comunities, Atena, Prisma, 2009;

6. ICĂ Jr., Ioan, „Globalizarea - mutații și provocări”, în Gândirea socială a Bisericii. Fundamente, documente, analize, perspective, volum realizat şi prezentat de Ioan Ică Jr. şi Germano Marani, Sibiu, Edit. Deisis, 2002, p. 481-498;

7. InstitutUl NAŢIONAL de STATISTICĂ: Rezultate definitive ale Recensământului Populaţiei şi al Locuinţelor-2011 (caracteristici demografice ale populatiei), 2011, disponibil la: http://www.recensamantromania.ro/wpcontent/uploads/2013/07/REZULTATE-DEFINITIVE-RPL_2011.pdf, (accesat la: 15. 03. 2019);

8. FERRARI, Silvio, „The Secular and Sacred in Europe's Constitution”, în The Spiritual and Cultural Dimension of Europe, Luxembourg, Office for Official Publications of the European Communities, 2005, p. 21-23;

9. LEMENI, Adrian, „Raportul dintre Stat şi Biserică în România în perspectiva integrării în Uniunea Europeană”, în Adrian GABOR, Radu Petre MuREŞAN (coord.), Biserica Ortodoxă în Uniunea Europeană. Contribuţii necesare la securitatea şi stabilitatea europeană, Bucureşti, Edit. Universităţii din Bucureşti, 2006, p. 144-152;

10. „Mesajul Prea Fericitului Părinte Patriarh Teoctist la Forumul Naţional U.E. 2007”, 14 februarie 2003, în Vestitorul Ortodoxiei, an XV (2003), nr. 308-309, p. 5;

11. MuReŞAN, Radu Petre, „Provocări și perspective ale Bisericii Ortodoxe în Uniunea Europeană”, în Adrian GABOR, Radu Petre MUREŞAN (coord.), Biserica Ortodoxă în Uniunea Europeană. Contribuţii necesare la securitatea şi stabilitatea europeană, Bucureşti, Edit. Universităţii din Bucureşti, 2006, p. 153-169;

12. NECULA, Nicolae D., „Cultul divin public ortodox, factor de stabilitate în viaţa credincioşilor", în Adrian GABOR, Radu Petre MUREŞAN (coord.), 
Biserica Ortodoxă în Uniunea Europeană. Contribuţii necesare la securitatea şi stabilitatea europeană, Bucureşti, Edit. Universităţii din Bucureşti, 2006, p. 21-26;

13. NECULA, Nicolae D., „Viaţa religioasă în Biserica Ortodoxă Română”, în vol: Biserica în Misiune. Patriarhia Română la ceas aniversar: 120 de ani de autocefalie (1885-2005), 80 de ani de Patriarhat (1925-2005), Bucureşti, EIBMBOR, 2005, p. 341-358;

14. PĂSTÎRNAC, Andreea, Interviu, disponibil la: http://www.mprp.gov.ro/web/ministrul-pentru-romanii-de-pretutindeniandreea-pastirnac-ma-uit-la-toti-cei-care-sunt-in-fata-noastra-ca-laparteneri-dintr-o-perspectiva-care-vreau-sa-ramana-onesta/ (accesat la: 18. 03. 2019);

15. POPESCU, Dumitru, „Omul fără rădăcini”, în Dumitru POPESCU (ed.), Știință și teologie: preliminarii pentru dialog, București, Edit. XXI: Eonul dogmatic, 2001, p. 291-300;

16. SANDU, Dumitru, „Cultură și experiență de migrație în satele României”, în: Sociologie Românească, Vol. II, Nr. 3/2004, p. 179-201;

17. VLAICU, Patriciu, „Românii din Europa Occidentală și Meridională”, în PS Ciprian CÂMPINEANU et all (eds.), Autocefalie și comuniune, volum apărut din inițiativa Preafericitului Părinte Daniel, Patriarhul Bisericii Ortodoxe Române, București, Edit. Basilica a Patriarhiei Române, 2010, p. 564-575. 